\title{
Geodiversity and biodiversity on a volcanic island: The role of scattered phonolites for plant diversity and reproductive fitness
}

David Kienle ${ }^{1, \mathrm{~A}}$, Anna Walentowitz ${ }^{1, \mathrm{~A}, \mathrm{~B}}$, Leyla Sungur ${ }^{1, \mathrm{~A}}$, Alessandro Chiarucci ${ }^{2}$, Severin D. H. Irl ${ }^{3}$, Anke Jentsch $^{4,5}$, Ole R. Vetaas ${ }^{6}$, Richard Field ${ }^{7}$ and Carl Beierkuhnlein ${ }^{1,5,8}$

$5 \quad{ }^{1}$ Biogeography, University of Bayreuth, Bayreuth, 95440, Germany

${ }^{2}$ BIOME Lab, Department of Biological, Geological and Environmental Sciences, Alma Mater Studiorum, University of Bologna, Bologna, 40126, Italy

${ }^{3}$ Biogeography and Biodiversity Lab, Institute of Physical Geography, Goethe-University Frankfurt, Frankfurt, 60438, Germany

$10{ }^{4}$ Disturbance Ecology, University of Bayreuth, Bayreuth, 95440, Germany

${ }^{5}$ Bayreuth Center of Ecology and Environmental Research BayCEER, University of Bayreuth, Bayreuth, 95440, Germany

${ }^{6}$ Department of Geography, University of Bergen, Bergen, 5020, Norway

${ }^{7}$ School of Geography, University of Nottingham, Nottingham, NG7 2RD, United Kingdom

${ }^{8}$ Geographical Institute Bayreuth, GIB, University of Bayreuth, Bayreuth, 95440, Germany

15

AThese authors contributed equally to this study.

${ }^{\mathrm{B}}$ Correspondence to: Anna Walentowitz (anna.walentowitz@uni-bayreuth.de)

Abstract. Oceanic islands are cradles of endemism, contributing substantially to global biodiversity. A similarity in magmatic origin translates into high global comparability of substrates of volcanic islands on the oceanic crust. In some

20 places, the petrography of magmatic rocks is differentiated chemically or physically. Phonolites are examples of rare localities with intermediate chemical traits between felsic and mafic and with diverse textures. They contribute to habitat heterogeneity and offer specific growth conditions in a significantly different matrix of basaltic substrates. The explicit contribution of geodiversity to island biodiversity has been little studied, despite accumulating evidence of its importance on continents. On the island of La Palma, Canary Islands, isolated phonolitic rocks are conspicuous by their light colour and specific shape. Although these outcrops only cover small areas, their unique form and composition increase within-island geodiversity. To investigate how this affects biodiversity on La Palma, we sampled all vascular plant species in 120 plots on four sets of paired sites, comparing phonolitic with basaltic rocks, to test whether phonolitic rocks increase overall plant species richness and promote the reproductive fitness of plants. We recorded species number and abundance, individual plant height, and diameter as proxies for aboveground resource allocation and tested for differences in vegetation cover and species composition between the bedrock types. We found higher species richness and abundance on phonolites than neighbouring basaltic substrates, and individuals of the same species were larger (in height and diameter) on phonolites compared to neighbouring basalt. An endemic woody species with two distinct varieties even appears almost exclusively on the small surfaces of phonolitic rock. Despite extremely limited spatial extent, phonolitic rocks can play an important role for plant biodiversity on islands. 
https://doi.org/10.5194/bg-2021-107

Preprint. Discussion started: 5 May 2021

(C) Author(s) 2021. CC BY 4.0 License.

(c) (i)

35

Biodiversity is known to depend mainly on abiotic drivers, such as climate and topography (Field et al., 2009). However, the importance and explicit impacts of geodiversity on biodiversity have long been under-researched; recently, they have started to receive more attention (Gray, 2004; Lawler et al., 2015; Bailey et al., 2017; Alahuhta, 2020; Barajas-Barbosa et al., 2020). Geodiversity is in many respects an abiotic equivalent to biodiversity (Gray, 2011) and represents the variability of geological elements (i.e., composition), surface structure, edaphic and hydrological features (Gray, 2004; Bailey et al., 2017). This variability contributes to habitat diversity and thus affects biodiversity patterns via the availability of ecological niches (Liu et al., 2013; Gillespie \& Roderick, 2014; Bailey et al., 2017). Geological elements provide unique or distinctive habitats for plants and insects, deliver initial growth conditions for vegetation or fungi formation, and are part of nutrient cycling and soil-atmosphere interactions (Tukiainen et al., 2016).

45

Biodiversity is distributed unevenly throughout the world (Gaston, 2000), and oceanic islands provide much of it due to their high endemic richness (Kier et al., 2009). Substrates that differ in geochemistry and petrography are likely to be relevant for biodiversity on oceanic islands, where most rocks commonly share similar volcanic genesis, resulting in only slight differences in the parent material. Distinct substrates with limited extent, such as individual rock types, may function as a second isolating abiotic filter for populations in addition to the spatial isolation of oceanic islands that are known to be of outstanding importance for speciation at the global scale (Kier et al. 2009). Specific rock habitats, particularly rocks that exhibit petrographic and geochemical substrates such as serpentinites, are known to be rich in habitat-specific endemics (e.g., Harrison et al., 2006; Kazakou et al., 2010). These species evolved specific adaptations to the unique nutrient contents and soil conditions and the presence of heavy metals that cannot be tolerated by other plant species (Harrison \& Rajakaruna,

55 2011). This phenomenon is also known from continental areas, where substrates such as serpentinite and gypsum outcrops host specialised floras and contribute to broad-scale diversity (see, e.g., Chiarucci et al., 1998; Pausas et al. 2003). Highly restricted ranges and small population sizes of insular endemic species make island biotas particularly vulnerable to extinction (Paulay, 1994) and underline the relevance of understanding the importance of geodiversity for insular biodiversity.

60

Phonolites are rocks that occur at volcanic intraplate settings in insular and continental contexts worldwide (Garcia et al., 1986; Ackerman et al., 2015; Hagos et al., 2017). They exist in a variety of forms in the context of volcanic activity. Such outcrops mainly exist on continents, where they are often linked to faults and tectonic activity. Major components of these extrusive igneous rocks (formed from lava with low silica content) are alkaline feldspars together with foid minerals, 65 nepheline, and pyroxene (Ackerman et al., 2015; Abratis et al., 2015) or their conversion products. Distinctive to phonolites is fine-to-medium grain size. 
https://doi.org/10.5194/bg-2021-107

Preprint. Discussion started: 5 May 2021

(c) Author(s) 2021. CC BY 4.0 License.

On the island of La Palma (Canary Islands, Spain), several phonolitic rock outcrops are embedded into a basaltic matrix (Middlemost, 1972). The dominant rock type found on La Palma is olivine and augite-titanaugite porphyric basalt, resulting

70 from rapidly rising magma from the upper mantle (Middlemost, 1970). In contrast, there were times when a sizeable magmatic chamber below the island enabled differentiation of magma, removal of silica and thus yielded ultramafic, trachytic, and phonolitic rocks (Middlemost, 1970). Phonolite trachytes (showing the exhalation of gases during eruptions) occur on various volcanic islands such as La Palma and St. Helena. On La Palma their distribution is focused on the southern (young) part of the island. The major chemistry of phonolites on La Palma is comparable to that of "average phonolites", as

75 described by Nockolds (1954).

Volcanic activity with the production of tephra and lava flows is a noticeably young phenomenon in the southern part of La Palma, with eruptions as recent as 1971. All recorded eruptions in this part took place in historic times. Thus, the remnant phonolitic rocks are the tips of a former land surface that are today embedded in a basaltic matrix of noticeably immature age

80 (Garantje et al., 1998). In consequence, weathering processes on phonolites were active on longer time scales compared to the surrounding rocks. In addition to petrography, differences in weathering and resulting nutrient availability refer to different time scales of exposure. Higher nutrient availability enables higher plant abundances and larger plant size. Porder et al. (2004) found comparable conditions at a catena of different rock ages in the Hawaiian Islands.

85 Compared to basaltic lava outcrops, phonolites differ in their chemical composition and, additionally, in colour, texture, density, weathering, and formation fracturing (von Fragstein et al., 1988). We observed tafoni-weathering (Formoso et al., 1989) on some phonolitic surfaces, indicating temperature and moisture gradients between the surface and the solid body of rocks (Brandmeier et al., 2011) combined with wind exposure. Circulating leachate reaches the rock's surface and evaporates, exposing its dissolved mineral content and enabling the development of secondary mineral assemblages (Spürgin et al., 2019) that can contribute to plant nutrient supply (Faccini et al., 2015, showed the effectiveness of ground phonolite rock powder as fertilizer). Even if quantitatively small, such processes are of particular importance at nutrient-poor sites. In contrast, the young basalts in the southern part of La Palma are barely weathered (Carracedo et al., 2001), appearing rough and friable with sharp spikes. We expect these petrographic and geochemical differences of parent material to affect vegetation cover and species occurrences.

La Palma hosts 149 vascular plant species that are endemic to the archipelago and 49 single island endemics (hereafter SIEs). The hyper-endemic plant species Cheirolophus junonianus, comprising its var. junonianus and var. isoplexiphyllus, (Vitales et al., 2014a; 2014b) occurs within a range of only $3500 \mathrm{~m}^{2}$, solely on La Palma (Bañares et al., 2004). Within this small range, individuals of this species occur only on a few outcrops, which are almost exclusively phonolitic rocks with a chemical composition different from most of the surrounding substrates. Therefore, the species is very restricted in its range size to just a few small locations (Muer et al., 2016; Atlantis, 2021) and appears to be restricted to phonolites (Fig. 1a). 
https://doi.org/10.5194/bg-2021-107

Preprint. Discussion started: 5 May 2021

(C) Author(s) 2021. CC BY 4.0 License.

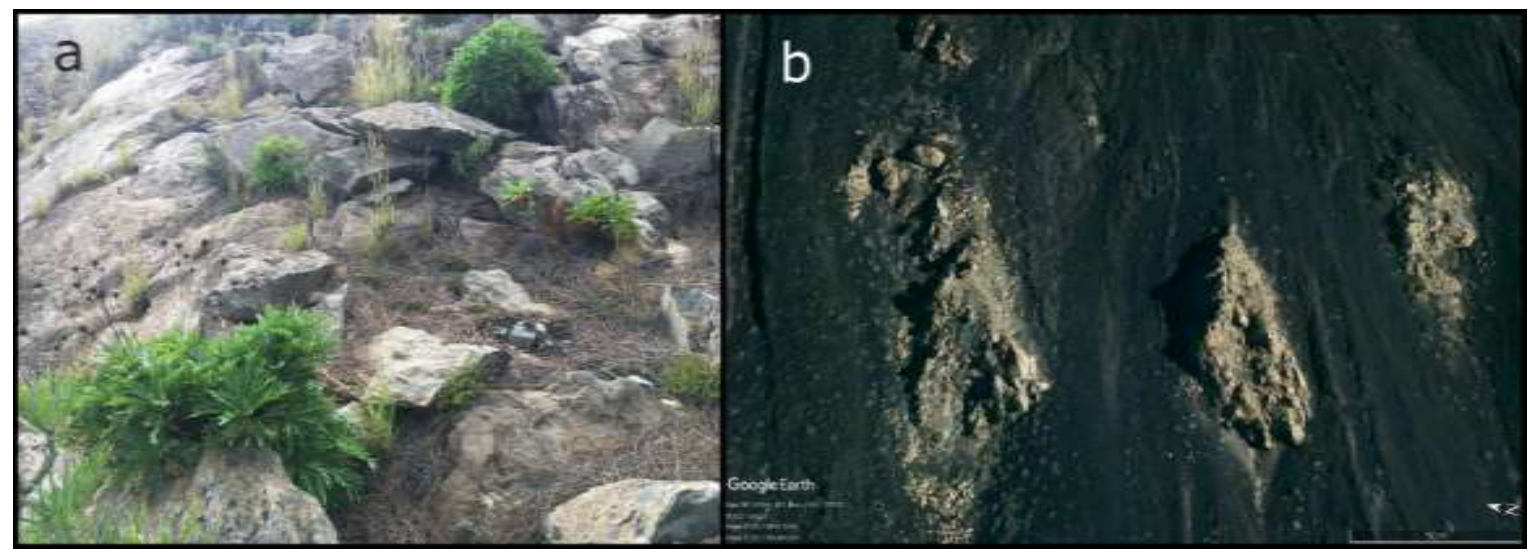

Figure 1: The endemic Cheirolophus junonianus (a, bottom-left) and further plant species on a phonolite rock (@) Severin Irl). Aerial image of rocks of phonolites isolated in a basaltic matrix in southern La Palma (b, (C) Google Earth 2020).

Geologic outcrops, such as phonolites, increase microenvironmental heterogeneity, enhancing species richness at a landscape scale (Hjort et al., 2015). Increased speciation rates on isolated outcrops of scarce rocks are thought to lead to a higher percentage of endemic species than the surrounding matrix (Ricketts, 2001). Geodiversity may thus promote both species richness and endemism. However, relatively little is known about the extent to which phonolites promote species diversity in general and particularly endemism. We aim to address this knowledge gap by investigating plant species richness and abundance on phonolites compared to surrounding basaltic lavas.

Phonolitic outcrops act as small habitat islands within a basaltic matrix (Fig. 1b). The established 'species-area relationship' (SAR) and the 'species-isolation relationship' (SIR) (MacArthur \& Wilson, 1967; Rosenzweig, 1995; Giladi et al., 2014)

115 predict a smaller number of species on these small and isolated phonolitic rocks in comparison with basaltic rock outcrops in their surroundings. (From the beginning (MacArthur \& Wilson, 1967), such concepts were not only meant for real islands but instead took 'islands' as examples for isolated habitats (or habitat islands) within a terrestrial landscape matrix.) However, the expected higher availability of nutrients would give such habitats more favourable conditions for plant growth. Besides, it is by no means certain that the phonolitic rocks were permanently separated from each other in southern La

120 Palma's geological evolution. Possibly, a historically much larger phonolitic rock is today largely buried by basaltic eruptions (Garantje et al., 1998). Thus, a few phonolite outcrops may serve as refugia for remnant populations (Eriksson, 1996) of species specialised to phonolitic rocks.

We investigated the occurrences and traits of plant species in a comparative study matching basaltic and phonolitic rock formations on La Palma of comparable size, shape and extent to test the following hypotheses: 
https://doi.org/10.5194/bg-2021-107

Preprint. Discussion started: 5 May 2021

(C) Author(s) 2021. CC BY 4.0 License.

(c) (i)

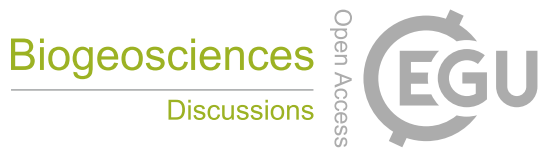

i. Species diversity: We expect plant species richness on phonolitic rocks to be higher than on basaltic rocks because phonolites offer more favourable plant growth conditions.

ii. Species reproductive fitness: Plant species populations on phonolites show a larger abundance of individuals that are taller and have greater canopy diameter than neighbouring basalts due to their advantages in resource availability and porosity. Plant height and canopy diameter were used as proxies for aboveground resource allocation and ultimately as a surrogate for fitness.

iii. Island endemism: We expect phonolitic rocks to host more endemic plant species than basaltic rocks because of their high degree of spatial isolation, in combination with the older age of the phonolitic bedrock than the basaltic matrix.

\section{Methods}

\subsection{Study site and data sampling}

140 We sampled four phonolitic and four adjacent basaltic rocks in the southern part of La Palma in spring 2018 (Walentowitz et al., submitted; Fig. 2). Locations were identified in the field based on Middlemost (1972). The sampled phonolitic rocks represented most of the overall extent of this habitat on the island, covering a large gradient of microclimate, aspect, and inclination. We chose comparable neighbouring pairs of phonolite and basalt consisting of one cohesive rock formation each. Outcrop pairs were chosen to match the size and microclimatic conditions (aspect, slope). For each selected phonolitic and

145 basaltic rock, we recorded plant species composition and abiotic parameters within 15 plots of $2 \mathrm{~m} \times 2 \mathrm{~m}$ that were randomly selected within the range of accessibility on the phonolite and basalt. This resulted in a total of 120 plots sampled across the four pairs of phonolitic and basaltic rocks (60 plots on phonolite and 60 plots on basalt in total). 


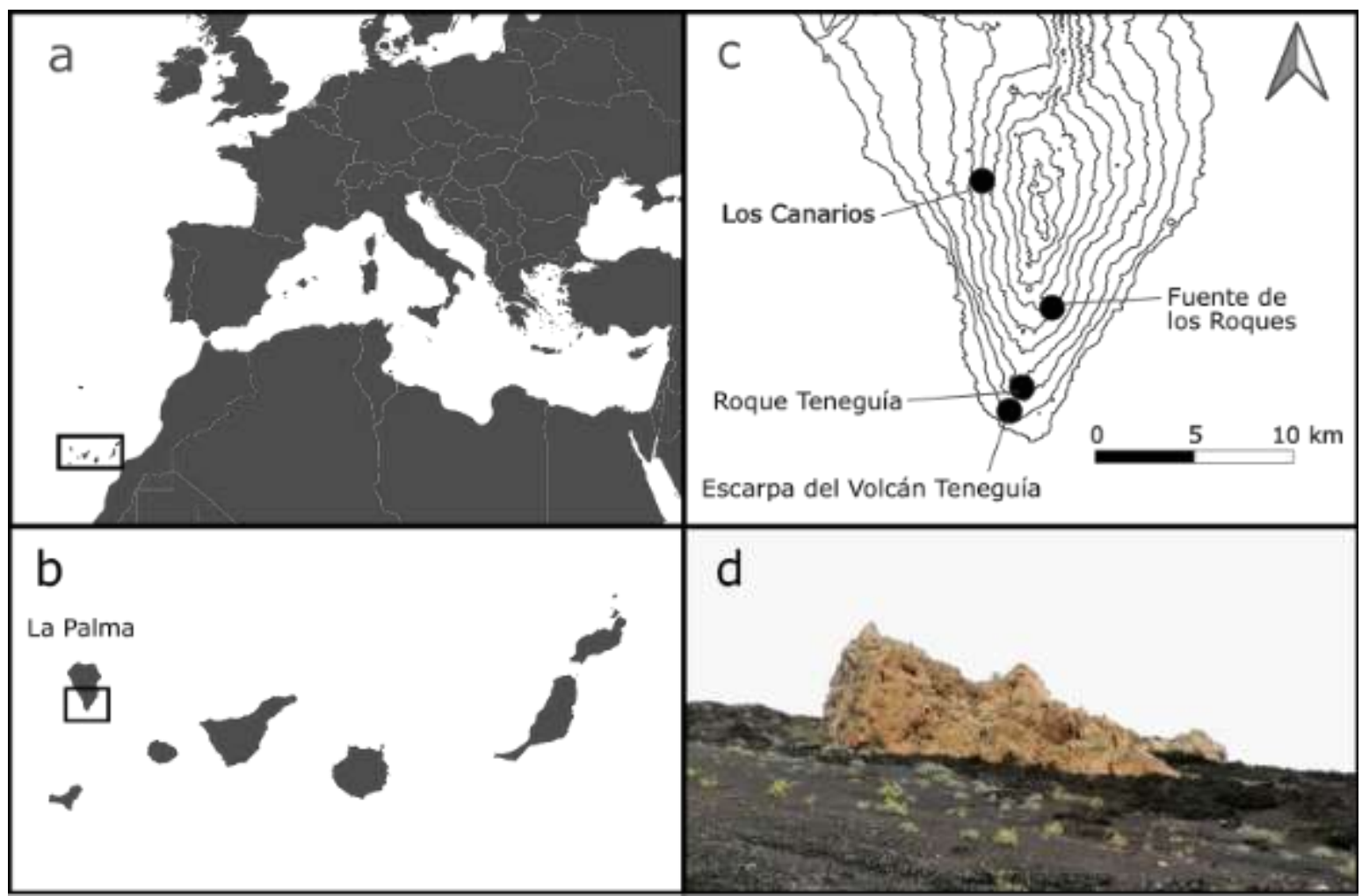

Figure 2: Location of the Canary Islands (a) and La Palma (b). Southern La Palma with our 4 study sites and contour lines at 200 m intervals (c). Phonolite rock on Southern La Palma downwards slopes of the "Roque Teneguía", located in a basaltic matrix (d, (C) Anna Walentowitz).

Within each plot, we recorded coordinates, aspect (northerness and easterness), and slope inclination. Then, we estimated rock surface rugosity using thread transects spanning the two plot diagonals: we measured the transect length along the 3Drock surface. Larger values of rugosity indicate higher levels of microtopography (cracks, hollows, uneven slope), while low values indicate smooth, even surfaces.

All vascular plant species within each plot, including ferns, were identified following the taxonomy of "Plants of the World online" (POWO, 2019). The biogeographic status of each species (single-island endemic, multi-island endemic, nonendemic native and introduced) is based on Muer et al. (2016) (see extensive plant list in Appendix A1). The number of individuals per species and plot was counted. Plant height (length from base of the stem to the tip) and canopy diameter (widest part of the plant parallel to the ground) of all single individuals found were measured as traits. Height, diameter, and species abundances were measured for species to ensure that vegetational differences evolved through long-term processes and did not reflect the short-term variability of environmental conditions. We are aware that numbers of flowers and seeds might be more accurate to measure reproductive fitness when monitoring plants over the course of an entire reproductive 
https://doi.org/10.5194/bg-2021-107

Preprint. Discussion started: 5 May 2021

(c) Author(s) 2021. CC BY 4.0 License.

(c) (i)

cycle, but we chose plant height and width as proxies as these can be measured within a short time frame. Lichen cover, which is abundant on the basalt, was estimated as the percent cover of each plot. Moss cover was negligible in all the plots.

\subsection{Statistical analysis}

Differences in total plant species number and the number of single and multi-island endemics were analysed using Pearson's

170 Chi-squared tests. Percentages of abundance, plant height, diameter, and SIE percentage between plots on phonolites and basalt were analysed using Mann-Whitney U tests. We conducted detrended correspondence analysis (DCA) to investigate the multidimensional aspects of vegetation composition and identify potential fundamental drivers (Appendix A3). We tested for differences in aspect, inclination, rock surface rugosity and lichen cover between phonolite and basalt using Mann-Whitney U tests.

\section{Results}

We recorded 68 species of vascular plants (pteridophtyes and spermatophtyes) overall. Of these species, nine were Single Island Endemics (SIE) restricted to the island of La Palma, 16 were Multi Island Endemics (MIE) co-occurring also on other islands in the archipelago, 39 were non-endemic natives, and 4 were non-natives. The SIE Cheirolophus junonianus was only found on phonolite, and most individuals of var. junonianus occurred on one isolated outcrop (Roque Teneguía) and individuals of var. isoplexiphyllus on another one (Escarpa del Volcán Teneguía, Fig. 2c).

We found higher plant species richness on phonolitic rocks. While 22 species were encountered on both phonolite and basalt, only eleven species were restricted to basalt, but 34 were recorded only on phonolite (Appendix A1). Endemism groupings showed similar patterns (SIEs - phonolite: 9, basalt: 5; MIEs - phonolite: 15, basalt: 6). Besides the total number of plant species per rock type, we also found higher species richness on phonolite at the plot scale $(\mathrm{p}=0.0164$, Fig. 3 a), and higher diversity of SIEs ( $p=0.00151$, Fig. 3 b) and MIEs ( $p=0.00727$, Fig. 3 d). The percentage of SIEs ( $p=0.1928$, Fig. 3 c) and MIEs ( $p=0.05346$, Fig 3 e) relative to total species number did not differ significantly at this scale between phonolitic and basaltic rocks. 

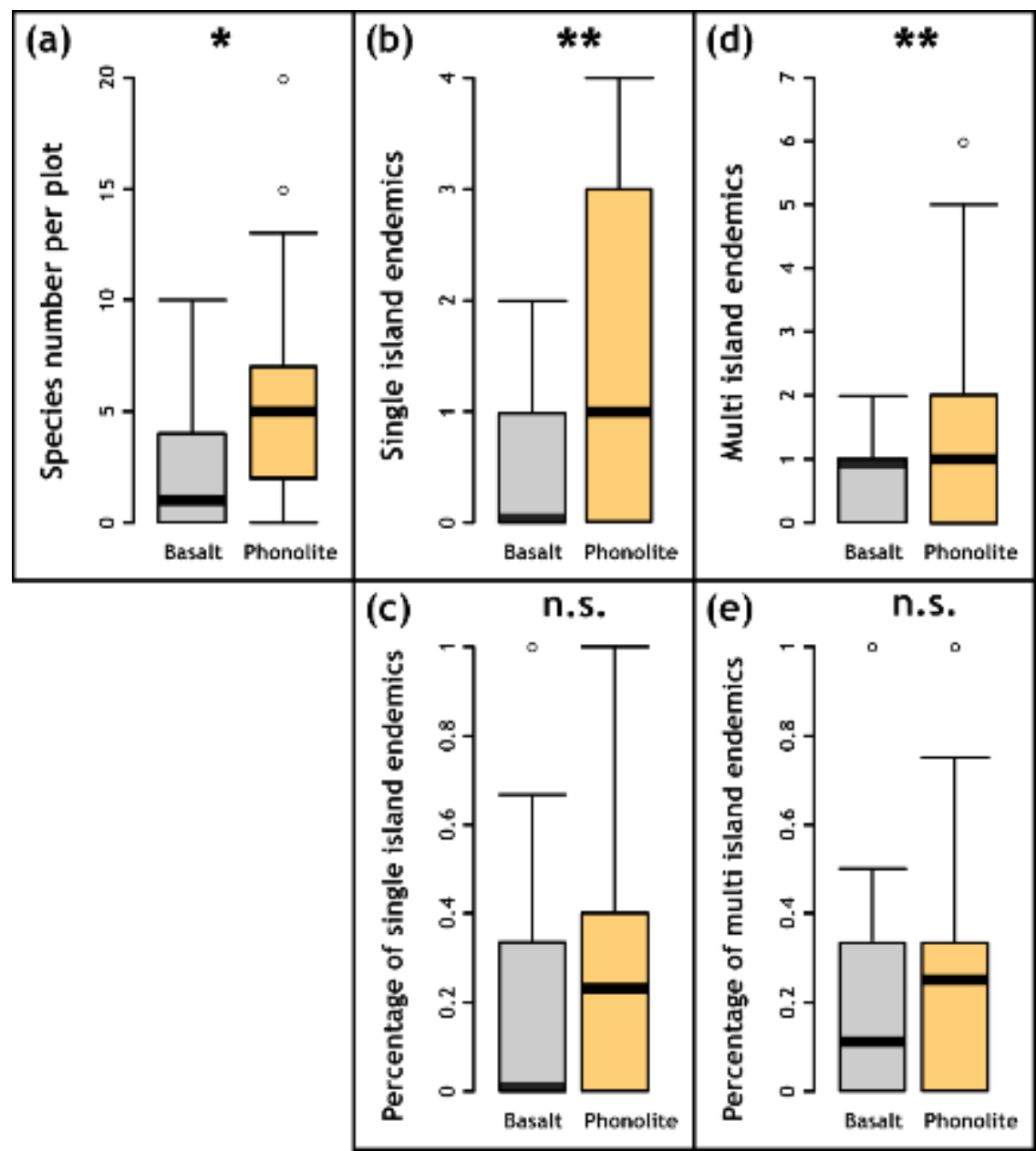

Figure 3: Perennial species per $2 \times 2 \mathrm{~m}$ plot for basaltic $(n=60)$ and phonolite substrates $(n=60)$. a) The number of species per phonolite plot is significantly larger than on basaltic plots. b) Phonolites have significantly more single island endemics (SIE) and (d) multi-island endemics. However, the numbers of endemic species relative to the total number of species do not differ significantly between substrates (c, e). All analyses were conducted with Pearson's Chi-squared test (a, b, c) and the MannWhitney $\mathrm{U}$ test (c, e).

On phonolitic rocks, we did not find higher total plant abundance $(\mathrm{p}=0.169$, Fig. 4 a). Moreover, there was no significant difference in abundance when only considering the 23 species found in plots on both substrates ( $p=0.179$, Fig. 4 b). 

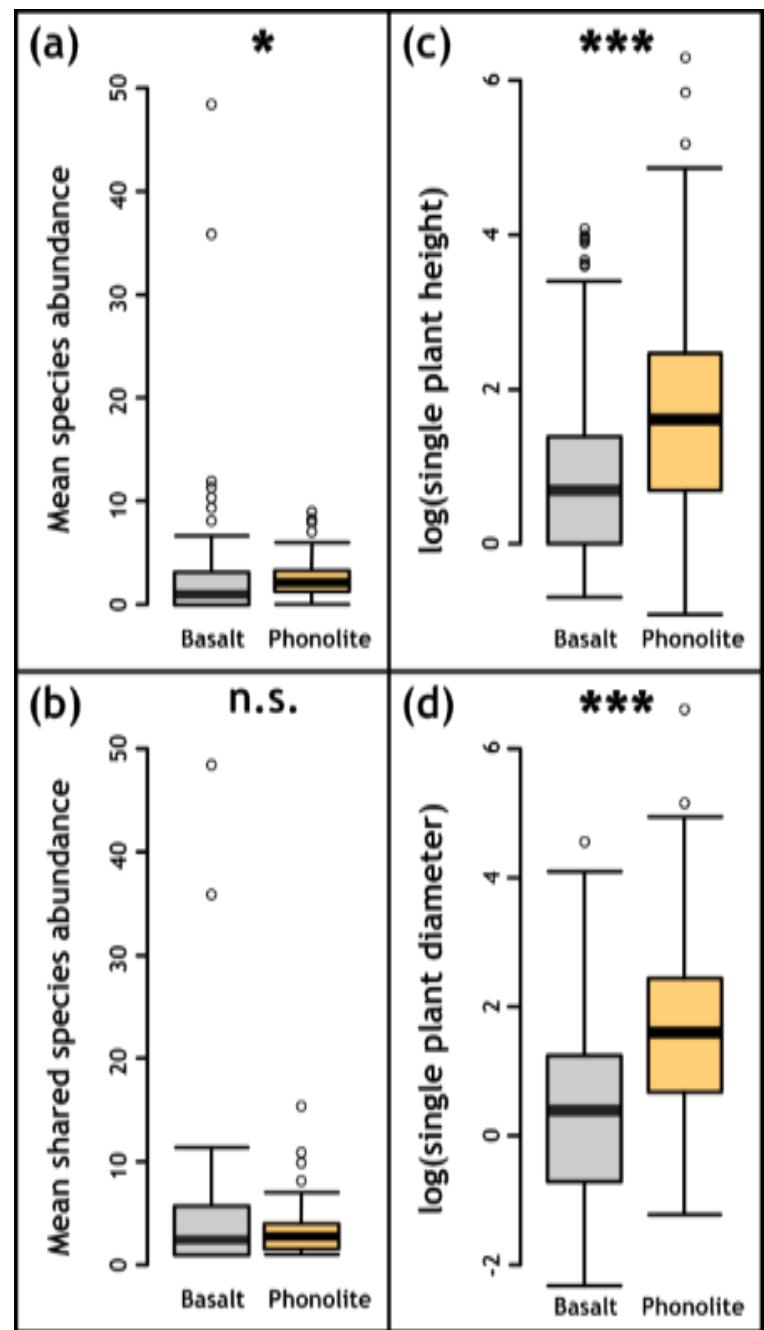

Figure 4: a) Mean abundance differs significantly between basaltic $(n=60)$ and phonolite substrates $(n=60)$, but b) considering only shared species on both substrates resulted in no significant difference between basalt $(\mathrm{n}=39)$ and phonolite $(\mathrm{n}=51)$. $\mathrm{c}$, d) Plant height and diameter (both log10-transformed) are significantly larger on phonolite plots $(n=1560)$ than on basaltic plots $(n$ = 1173). Plot size: $2 \times 2 \mathrm{~m}$. All analyses were conducted with the Mann-Whitney $U$ test.

For plant species recorded on both rock types, individuals were on average taller and had wider canopies (Fig. 4c-d) on phonolitic than on basaltic rocks (Fig. 4c-d).

Plant cover only (excluding lichens) was also significantly higher ( $<$ 0.0001, Appendix A2a) on phonolites than on basalt. Lichen cover did not show a significant difference $(\mathrm{p}=0548$, Appendix A2b). 
https://doi.org/10.5194/bg-2021-107

Preprint. Discussion started: 5 May 2021

(c) Author(s) 2021. CC BY 4.0 License.

(c) (i)

210 The ordination did not show any difference in the species composition, indicating no aspects of beta-diversity at all (Appendix A3). Topographic characteristics of basalt and phonolite plots showed no differences in surface rugosity, aspect (northerness, easterness), or differences in slope inclination (Appendix A4).

\section{Discussion}

Phonolites host distinct vegetation compared to equivalent areas of neighbouring basaltic rocks. The vegetation on phonolitic

215 rocks is characterized by higher species richness and higher reproductive fitness of plant individuals and higher total plant cover.

Phonolite rocks on La Palma and other oceanic islands are arranged as habitat islands in a basaltic matrix (Fig. 1b). On La Palma, the total area of phonolite outcrop is tiny compared with the area of the basaltic matrix. Thus, encountering more

220 species on phonolites than on basalt aligns with our hypotheses but defies the area effect on species richness, which predicts species number to be lower in the phonolite habitat. This makes the greater number on phonolite even more remarkable. However, our findings are congruent with studies which did not find a species-area relationship or relationships with a less steep slope on habitat islands (Matthews et al., 2016; Deák et al., 2018). Reasons might be unrealised niches due to unsaturated evolutionary dynamics in this young and isolated system. Environmental filters (Liu et al., 2020) enhancing

225 growth conditions on phonolite outcrops may also exist, consistent with our findings that the plants are larger on phonolites. Several mutually non-exclusive drivers may explain this phenomenon: 1) phonolite-specific surface texture, 2) colour, 3) chemistry, and 4) age.

1) We observed deeper fractures in phonolitic rocks than in other volcanites on La Palma Island. Besides, phonolitic rocks 230 show a much smoother surface roughness than their surrounding matrix. Basaltic rocks seem to possess a more dynamic relief, mainly attributed to their origin in congealed lava flows, typically found on oceanic islands. When testing rock surface rugosity, there were no significant differences between phonolitic and basaltic rocks. Hence, we argue that surface texture does not play a role for higher plant growth response, richness and abundance observed on phonolites.

235 2) Most phonolitic rocks in a basaltic matrix are visually brighter than basalt. We expected that phonolites hold a higher albedo than surrounding rocks and therefore expected them to have a reduced surface temperature compared to volcanic outcrops with darker colouring, such as basalt. However, in an experiment with differently coloured bricks Hall et al. (2005) showed that the albedo of white surfaces only leads to significantly lower temperature of the material when the surface temperature falls below air temperature. With monthly temperatures between 17 and $25^{\circ} \mathrm{C}$ within large areas of oceanic 240 islands (Harter et al., 2015), no major temperature differences between basalt and phonolite surfaces can be expected. We therefore consider that this effect has no major impact on plants' habitat suitability. 
https://doi.org/10.5194/bg-2021-107

Preprint. Discussion started: 5 May 2021

(C) Author(s) 2021. CC BY 4.0 License.

3) Grain size and the rather porphyric arrangement of phonolites imply ameliorating plant growing conditions on this rock type. The chemical composition of phonolites has been described as nutrient-rich as it has traditionally been ground up and used as an inorganic fertilizer (von Wilpert \& Lukes, 1998; Ramos et al., 2006; Schoen et al., 2016). Phonolites consist of the potassium-rich nepheline, which dissolves much faster than other potassium sources (Manning, 2009). This may explain increased plant growth on phonolites. Weathering processes may act as driving forces for the establishment and germination of plants as they increase plant-available nutrients on these outcrops. Since ground phonolitic rock fertilizer is used to provide crops and trees with potassium (von Wilpert \& Lukes, 1998; Schoen et al., 2016), plants growing on phonolites might profit from this rock characteristic. Basaltic rock powder has also been used as fertilizer in rare cases, but according to Manning (2009) this is mainly due to geologically unclear assignments (potassium-rich trachyte is often assigned to basalt). Furthermore, he points out that basalt is another but smaller source of potassium than phonolite.

4) The age of geological formations influences plant diversity and species composition (Whittaker et al., 2008; Hulshof \& Spasojevic, 2020). As noted in previous studies (Carracedo et al., 2001), the Cumbre Vieja rift on La Palma has evolved throughout several eruptions and therefore contains lava formations from different ages as well as slightly different mineralogical compositions. The known phonolite rocks on La Palma are located in the geologically young southern part of the island. Consequently, we can assume that they are all in a stage of high ecological opportunities resulting in unsaturated niches (Whittaker et al. 2008). An interplay between erosion-driven uncovering of lava-covered phonolite rocks and new lava flows may strongly influence the vegetation on those rocks. We observed partly buried phonolites on which the survival of plants or seedlings during volcanic events was improbable (Garantje et al., 1998). Carracedo et al. (2001) showed that the last phonolite formation occurred in 1585, while there have been basaltic outbreaks until 1977. Thus, age differences between phonolitic and basaltic outcrops might influence plant composition and performance. A geological map provided by Carracedo et al. (2001) shows that most phonolitic rocks surrounded by lava flows are much older than 1585 .

The differential geology itself results in a specialized flora of those habitat islands (Kruckerberg, 1991). Even though the hyper-endemic Cheirolophus junonianus with its two varieties var. junonianus and var. isoplexiphyllus is confined to phonolites, the percentage of single island endemics on phonolites was not significantly higher, refuting our expectations, though the numbers of endemic species were significantly higher. Lessons learned from other outcrops (Kruckerberg, 1991) cannot be applied to phonolitic rocks on La Palma, and the functioning of phonolites as islands of speciation within a sea of basalt does not seem to apply. However, as most individuals of the typical variety of Cheirolophus junonianus occur on one isolated outcrop and individuals of var. isoplexiphyllus on another one (personal observation), a very local allopatric speciation by adaptive radiation or an ongoing genetic drift could be the underlying cause (Vitales et al., 2014a; 2014b). One possible explanation for this singularity presumes Cheirolophus junonianus belongs to a relict population of plants that were once widely distributed on phonolitic rock before these were covered mainly in a basaltic matrix. Species composition might 
https://doi.org/10.5194/bg-2021-107

Preprint. Discussion started: 5 May 2021

(c) Author(s) 2021. CC BY 4.0 License.

(c) (i)

be influenced by age differences of underlying rock material as species like Cheirolophus junonianus and its var. junonianus and var. isoplexiphyllus can solely be encountered on phonolitic rocks (Muer et al., 2016). It is well known that habitat diversity on islands leads to higher species richness (Hortal et al., 2009). Phonolites offer an added habitat for plants to grow on and contribute to plant species richness and endemism on La Palma (Irl et al., 2015).

When looking at the role of geologic promotion of biodiversity, there are several studies addressing serpentinite rocks and serpentine soils. On those rocks and soils, considerable amounts of toxic heavy metals, low amounts of essential nutrients $(\mathrm{N}, \mathrm{K}$, and $\mathrm{P}$ ), and a low calcium-to-magnesium ratio relate to high rates of endemism and a specialized flora (Chiarucci, 2003; Harrison et al., 2006). These serpentinite-tolerating species are restricted to a harsh environment by dominant competitors in a less harsh matrix. On phonolitic rocks, more favourable growing conditions resulting in higher plant richness and abundances seem to prevail. Compared to serpentinite rock studies, the surrounding matrix is built up by the potentially harsher basaltic rocks resulting in lower plant growth response.

The geological history of basaltic rocks depends on a series of different volcanic eruptions, assuming a more considerable chemical variability, whereas phonolites seem to build upon one or just a few volcanic events (Carracedo et al., 2001). The long chronology of volcanic eruptions on the Canary Islands and their ancestors reveals a high likeliness that most of the eruptions resulted in basaltic, only a few in phonolitic formations. Plants growing on basalt experienced larger environmental gradients since basalt is omnipresent on the islands. Contrasting, plants growing only on phonolites did not experience larger environmental gradients. In accordance, we observed plants on basaltic rocks to be more generalist than plants on phonolitic rocks.

We are not aware of other studies conducted in locations where phonolites can be encountered that explore their potential role as exceptional plant habitat islands, even though phonolites can be found all over the world (Garcia et al., 1986; Ackerman et al., 2015; Hagos et al., 2017). Therefore, further investigation is needed to figure out whether the patterns encountered on La Palma may also be found on comparable phonolitic rocks in other areas of the world. Their benefits for biodiversity found in this study need to be recognized and valued. Especially for isolated areas such as islands, phonolites can contribute to small-scale biodiversity hotspots and our findings suggest that they should be conserved.

\section{Conclusion}

Phonolites provide unique habitat conditions on oceanic islands and exhibit distinct vegetation compared with surrounding areas. Higher species numbers and abundances as well as higher plant growth responses underline the importance of these rocks for the vegetation on these islands which are globally dispersed. Despite the small area covered by phonolites they play a significant role in enhancing plant biodiversity. Our results contribute to a better understanding of the distribution and plant 
diversity drivers on islands through exceptional rock outcrops like phonolites. As oceanic islands have always been formed through volcanic activity on the oceanic crusts, the combination of basaltic and phonolitic rocks is highly likely a regular pattern in Earth history.

\section{Appendix}

A1: Complete list of all species encountered on phonolites (P) and basalt (B) including their status as single island endemic (SIE), multi-island endemic (MIE), native (nat.) and introduced (intr.). The taxonomy follows the standards of "Plants of the World online" (POWO 2019).

\begin{tabular}{|c|c|c|c|c|c|}
\hline Species & Family & $\begin{array}{l}\text { Rock } \\
\text { type }\end{array}$ & Status & woody & perennial \\
\hline Aeonium arboreum ssp. holochrysum (H.Y.Liu) Bañares & Crassulaceae & $\mathrm{B} / \mathrm{P}$ & MIE & 1 & 1 \\
\hline Aeonium diplocyclum (Webb ex Bolle) T.H.M.Mes & Crassulaceae & $\mathrm{B}$ & MIE & 1 & 1 \\
\hline Aichryson bollei Webb ex Bolle & Crassulaceae & $\mathrm{P}$ & SIE & 0 & 1 \\
\hline Allium canariense (Regel) N.Friesen \& P.Schönfelder & Amaryllidaceae & $\mathrm{P}$ & MIE & 0 & 1 \\
\hline Anogramma leptophylla (L.) Link & Pteridaceae & $\mathrm{B}$ & nat. & 0 & 0 \\
\hline Anthoxanthum odoratum L. & Poaceae & $\mathrm{P}$ & nat. & 0 & 1 \\
\hline Arabidopsis thaliana (L.) Heynh. & Brassicaceae & $\mathrm{B} / \mathrm{P}$ & nat. & 0 & 0 \\
\hline Astydamia latifolia (L.f.) Baill. & Apiaceae & $\mathrm{P}$ & nat. & 1 & 1 \\
\hline Bituminaria bituminosa (L.) C.H.Stirt. & Fabaceae & $\mathrm{P}$ & nat. & 1 & 1 \\
\hline Brassica oleracea L. & Brassicaceae & $\mathrm{B}$ & intr. & 0 & 1 \\
\hline Bystropogon origanifolius var. palmensis & Lamiaceae & $\mathrm{B} / \mathrm{P}$ & SIE & 1 & 1 \\
\hline Cardamine hirsuta $\mathrm{L}$. & Brassicaceae & B & nat. & 0 & 0 \\
\hline Cheirolophus junonianus (Svent.) Holub & Asteraceae & $\mathrm{P}$ & SIE & 1 & 1 \\
\hline Cosentinia vellea ssp. bivalens (Reichstein) Rivas Mart. \& Salvo & Pteridaceae & $\mathrm{B} / \mathrm{P}$ & nat. & 0 & 1 \\
\hline Crassula campestris (Eckl. \& Zeyh.) Endl. & Crassulaceae & $\mathrm{B}$ & intr. & 0 & 0 \\
\hline Festuca muralis Kunth & Poaceae & $\mathrm{B}$ & nat. & 0 & 0 \\
\hline Filago germanica $($ L.) Huds. & Asteraceae & B & nat. & 0 & 0 \\
\hline
\end{tabular}




\begin{tabular}{|c|c|c|c|c|c|}
\hline Galium aparine $\mathrm{L}$. & Rubiaceae & $\mathrm{B} / \mathrm{P}$ & nat. & 0 & 0 \\
\hline Geranium molle L. & Geraniaceae & $\mathrm{P}$ & nat. & 0 & 0 \\
\hline Geranium purpureum Vill. & Geranicaeae & $\mathrm{P}$ & nat. & 0 & $\overline{0}$ \\
\hline Hemionitis guanchica (Bolle) Christenh. & Pteridaceae & $\mathrm{B} / \mathrm{P}$ & nat. & 0 & 1 \\
\hline Holcus lanatus L. & Poaceae & $\mathrm{P}$ & nat. & 0 & 1 \\
\hline Kleinia neriifolia Haw. & Asteraceae & $\mathrm{P}$ & MIE & 1 & 1 \\
\hline Lavandula canariensis Mill. & Lamiaceae & $\mathrm{P}$ & MIE & 1 & 1 \\
\hline Lobularia canariensis (DC.) L.Borgen & Brassicaceae & $\mathrm{P}$ & MIE & 1 & 1 \\
\hline Medicago truncatula Gaertn. & Fabaceae & $\mathrm{P}$ & nat. & 0 & 0 \\
\hline Monanthes muralis (Webb ex Bolle) Hook.f. & Crassulaceae & $\mathrm{B} / \mathrm{P}$ & MIE & 0 & 1 \\
\hline Ononis serrata Forssk. & Fabacea & $\mathrm{P}$ & nat. & 0 & 0 \\
\hline Opuntia ficus-indica (L.) Mill. & Cactaceae & $\mathrm{P}$ & intr. & 1 & 1 \\
\hline Parietaria debilis G.Forst. & Urticaceae & $\mathrm{P}$ & nat. & 0 & 0 \\
\hline Paronychia canariensis (L.f.) Link & Caryophyllaceae & $\mathrm{P}$ & MIE & 1 & 1 \\
\hline Periploca laevigata Aiton & Apocynaceae & $\mathrm{P}$ & nat. & 1 & 1 \\
\hline Phagnalon purpurascens Sch.Bip. & Asteraceae & $\mathrm{P}$ & nat. & 1 & 1 \\
\hline Pinus canariensis C.Sm. ex DC. & Pinaceae & $\mathrm{P}$ & MIE & 1 & 1 \\
\hline Rubia fruticosa Aiton & Rubiaceae & $\mathrm{P}$ & nat. & 1 & 1 \\
\hline Rumex bucephalophorus ssp. canariensis (Steinh.) Rchb.f. & Polygonaceae & $\mathrm{B}$ & nat. & 1 & 1 \\
\hline Rumex lunaria L. & Polygonaceae & $\mathrm{B} / \mathrm{P}$ & MIE & 1 & 1 \\
\hline Schizogyne sericea (L.f.) DC. & Asteraceae & $\mathrm{B} / \mathrm{P}$ & nat. & 1 & 1 \\
\hline Sideritis barbellata Mend.-Heuer & Lamiaceae & $\mathrm{B} / \mathrm{P}$ & SIE & 1 & 1 \\
\hline Solanum villosum Mill. & Solanaceae & $\mathrm{P}$ & nat. & 0 & 1 \\
\hline Sonchus hierrensis (Pit.) Boulos & Asteraceae & $\mathrm{P}$ & MIE & 1 & 1 \\
\hline Sonchus oleraceus L. & Asteraceae & $\mathrm{B} / \mathrm{P}$ & nat. & 0 & 0 \\
\hline Stachys arvensis (L.) L. & Lamiaceae & $\mathrm{B} / \mathrm{P}$ & nat. & 0 & 0 \\
\hline Todaroa aurea (Aiton) Parl. & Apiaceae & $\mathrm{P}$ & MIE & 0 & 1 \\
\hline Tolpis laciniata $\mathrm{Webb}$ & Asteraceae & $\mathrm{B} / \mathrm{P}$ & MIE & 0 & 1 \\
\hline
\end{tabular}


https://doi.org/10.5194/bg-2021-107

Preprint. Discussion started: 5 May 2021

\begin{tabular}{|l|l|c|c|c|c|}
\hline Trifolium arvense $\mathrm{L}$. & Fabaceae & $\mathrm{B}$ & nat. & 0 & 0 \\
\hline Tuberaria guttata $(\mathrm{L}$.$) Fourr.$ & Cistaceae & $\mathrm{B}$ & nat. & 0 & 1 \\
\hline Umbilicus gaditanus Boiss. & Crassulaceae & $\mathrm{B} / \mathrm{P}$ & nat. & 0 & 1 \\
\hline Valeriana dentata (L.) All. & Valerianaceae & $\mathrm{P}$ & intr. & 0 & 0 \\
\hline Wahlenbergia lobelioides (L.f.) Link ssp. lobelioides & Campanulaceae & $\mathrm{B}$ & nat. & 0 & 0 \\
\hline
\end{tabular}

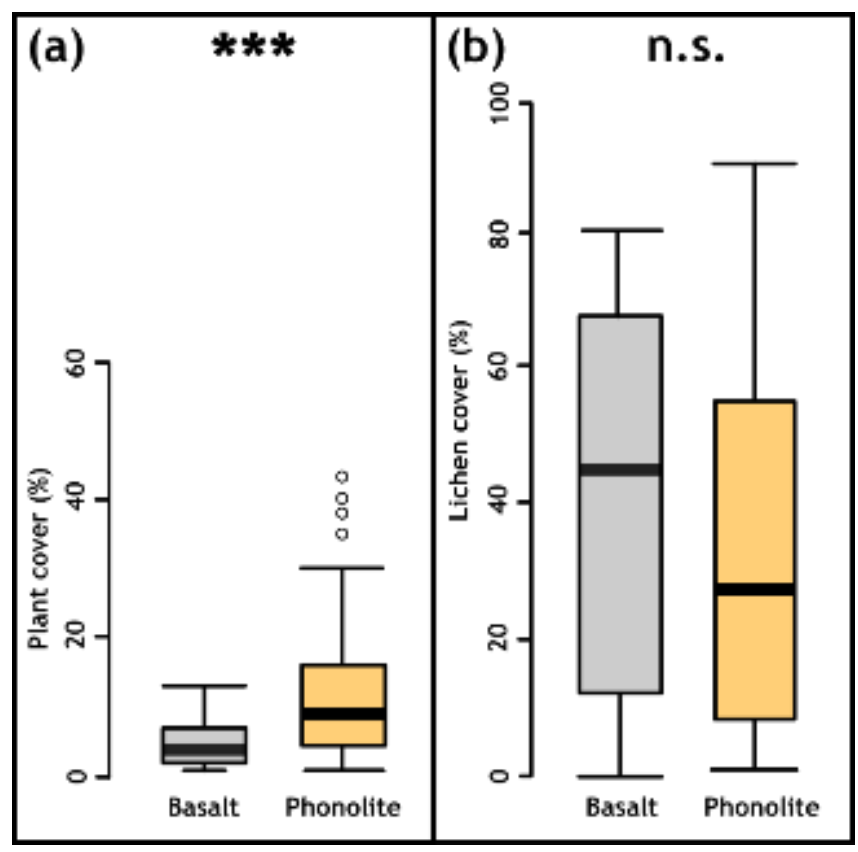

A2: Vegetation cover on basaltic and phonolite plots. (a) Plant cover showed the same result, p $<0.001$, Mann-Whitney U test). (b) Lichen cover showed no significant difference between the substrates $(p>0.05$, Mann-Whitney $U$ test). 
https://doi.org/10.5194/bg-2021-107

Preprint. Discussion started: 5 May 2021

(c) Author(s) 2021. CC BY 4.0 License.

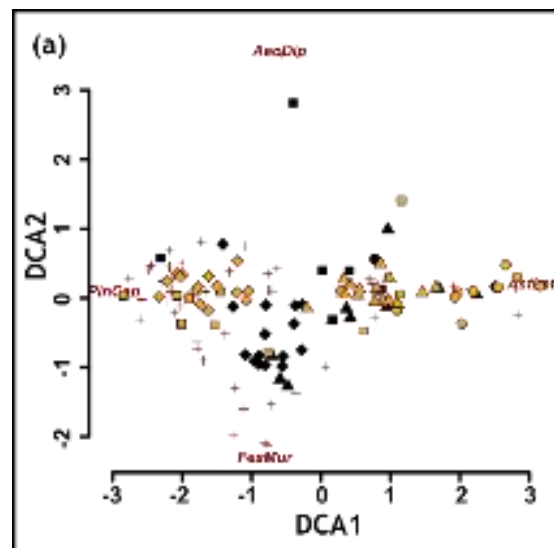

(d)

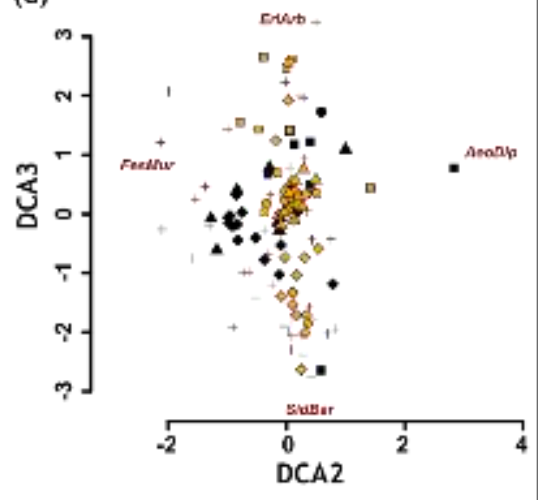

(b)

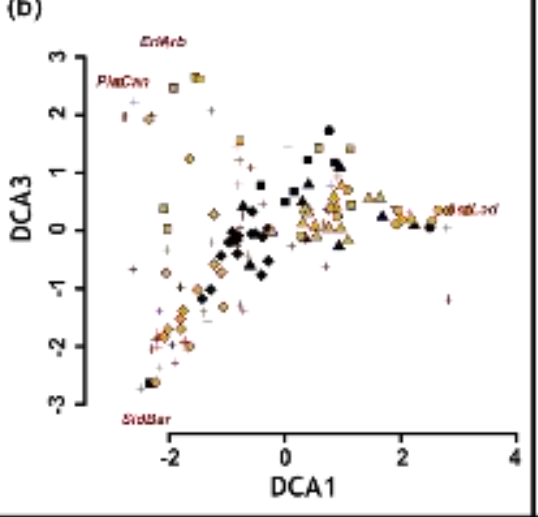

(e)

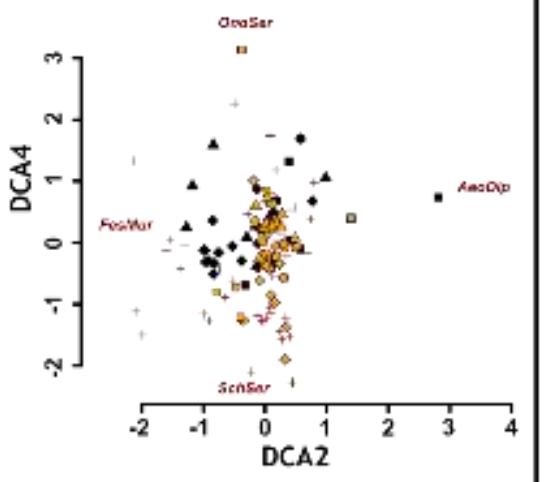

$(c)$

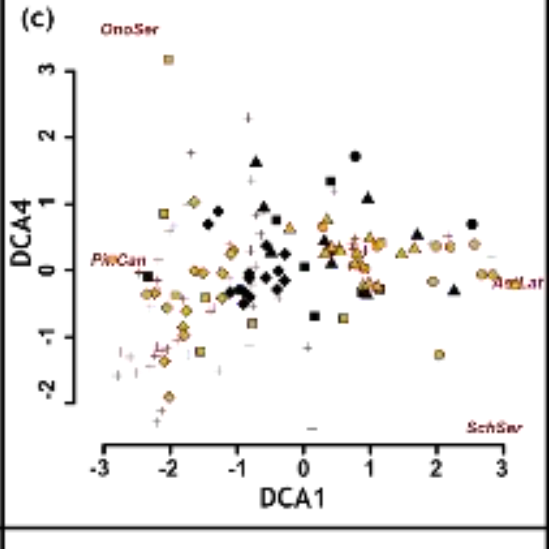

(f)

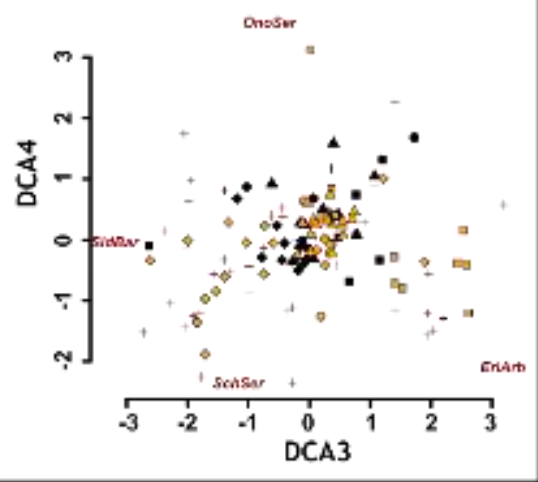

A3: Detrended Correspondence Analyses (DCA) shows no clear difference between phonolite and basaltic rock vegetations. Yellow dots show phonolite plots, black dots basalt plots, dark red a subset of species centroids. Species names chosen based on most extreme values along the gradients.

A4: Environmental plot characteristics. Inclination on phonolites was (despite efforts to sample similar environments) significantly higher than on basalt. Components of exposition (northerness and easterness) and rugosity showed no significant differences (unpaired Whitney test).

\begin{tabular}{|l|l|l|l|l|}
\hline & Rugosity $(\mathbf{m})$ & Northness & Eastness & Inclination $\left(^{\circ}\right)$ \\
\hline Mean Basalt & 3.557 & 0.01407 & 0.04970 & 43.0 \\
\hline Mean Phonolite & 3.643 & -0.09062 & 0.04303 & 53.8 \\
\hline p-Value & 0.7781 & 0.6525 & 0.8827 & 0.0277 \\
\hline
\end{tabular}

\section{Code availability}

Only standard tests and plotting commands in $\mathrm{R}$ were used for data analysis. The code is available on request from the corresponding author. 
https://doi.org/10.5194/bg-2021-107

Preprint. Discussion started: 5 May 2021

(c) Author(s) 2021. CC BY 4.0 License.

(c) (i)

\section{Data availability}

Any data supporting the findings of this study are available within the supplementary materials of this article and were taken from Walentowitz et al. [submitted].

\section{Authors contributions}

340 C.B., S.D.H.I., D.K., L.S. and A.J.W. developed the research idea, D.K., L.S. and A.J.W. conducted the field work, analysed the data and led the writing process. All authors developed the methods, discussed the results and contributed to the manuscript.

\section{Competing interests}

The authors declare that they have no conflict of interest.

\section{Acknowledgements}

We would like to kindly thank the technical staff of the Biogeography Department of the University of Bayreuth for supporting this study and being of immense help in the implementation of field work. The Caldera de Taburiente National Park Directorate and especially Felix Medina from the Consejería de Medio Ambiente, Cabildo de La Palma, are being thanked for permitting investigations in protected areas on La Palma and for their expertise on the local flora. This project has received funding from the European Union's Horizon 2020 research and innovation programme ECOPOTENTIAL under grant agreement No 641762. The work on this study is additionally supported by the pilot mySpace in the Horizon 2020 project e-shape under grant agreement No 820852.

\section{References}

Abratis, M., Viereck, L., Pfänder, J. A. and Hentschel, R.: Geochemical composition, petrography and 40Ar/39Ar age of the Heldburg phonolite: implications on magma mixing and mingling, Int. J. Earth. Sci., 104, 2033-2055, https://doi.org/10.1007/s00531-015-1207-x, 2015.

Ackerman, L., Ulrych, J., Randa, Z., Erban, V., Hegner, E., Magna, T., Balogh, K., Frána, J., Milos, L. and Novák, J. K.: Geochemical characteristics and petrogenesis of phonolites and trachytic rocks from the České Středohoří Volcanic Complex, the Ohře Rift, Bohemian Massif, Elsevier Lithos, 224-225, 256-271, https://doi.org/10.1016/j.lithos.2015.03.014, 3602015.

Alahuhta, J., Toivanen, M. and Hjort, J. Geodiversity-biodiversity relationship needs more empirical evidence, Nat Ecol Evol, 4, 2-3, https://doi.org/10.1038/s41559-019-1051-7, 2020.

Atlantis 2021 Biodiversity Data Bank of the Canary Islands, Gobierno de las Canarias, 2021. 
https://doi.org/10.5194/bg-2021-107

Preprint. Discussion started: 5 May 2021

(c) Author(s) 2021. CC BY 4.0 License.

Bailey, J. J., Boyd, D. S., Hjort, J., Lavers, C. P. and Field, R.: Modelling native and alien vascular plant species richness: at which scales is geodiversity most relevant? Glob. Ecol. Biogeogr., 26, 763-776, https://doi.org/10.1111/geb.12574, 2017.

Bañares, A., Blanca, G., Güemes, J., Moreno, J. C. and Ortiz, S. (eds): Atlas y libro rojo de la flora vascular amenazada de España. Ministerio de Medio Ambiente, Madrid, 2004.

Barajas-Barbosa, M. P., Weigelt, P., Booregaard M. K., Keppel G. and Kreft H.: Environmental heterogeneity dynamics drive plant diversity on oceanic islands, J. Biogeogr, 00, 1-13, https://doi.org/10.1111/jbi.13925, 2020.

Brandmeier, M., Kuhlemann, J., Krumrei, I., Kappler, A. and Kubik, P. W.: New challenges for tafoni research. A new approach to understand processes and weathering rates, Earth Surf. Proc. Land., 36, 839-852, https://doi.org/10.1002/esp.2112, 2011.

Carracedo, J. C., Day, S. J., Guillou H. and Gravestock P.: Later stages of volcanic evolution of La Palma, Canary Islands: Rift evolution, giant landslides, and the genesis of the Caldera de Taburiente, GSA Bulletin, 111, 755-768, https://doi.org/10.1130/0016-7606(1999)111<0755:LSOVEO>2.3.CO;2, 1999.

Chiarucci, A., Robinson, B. H., Bonini, I., Petit, D., Brooks, R. R. and De Dominicis, V.: Vegetation of tuscan ultramafic soils in relation to edaphic and physical factors, Folia Geobot., 33, 113-131, https://doi.org/10.1007/BF02913340, 1998.

Chiarucci, A.: Vegetation ecology and conservation on Tuscan ultramafic soils. The Botanical Review, 69, 252-268, https://doi.org/10.1663/0006-8101(2003)069[0252:VEACOT]2.0.CO;2 , 2003.

380 Deák, B., Valkó, O., Török, P., Kelemen, A., Bede, A., Csathó, A. I. and Tóthmérész, B.: Landscape and habitat filters jointly drive richness and abundance of specialist plants in terrestrial habitat islands. Landscape Ecol., 33, 1117-1132, https://doi.org/10.1007/s10980-018-0660-x, 2018.

Eriksson, O.: Regional dynamics of plants: a review of evidence for remnant, source-sink and metapopulations. Oikos, 77, 248-258, doi:10.2307/3546063, 1996.

385 Faccini, B., Di Giuseppe, D., Malferrari, D., Coltorti, M., Abbondanzi, F., Campisi, T., Laurora, A. and Passaglia, E.: Ammonium-exchanged zeolitite preparation for agricultural uses: from laboratory tests to large-scale application in ZeoLIFE project prototype, Periodico di Mineralogia, 84, http://dx.doi.org/10.2451/2015PM0015, 2015.

Field, R., Hawkins, B. A., Cornell, H. V., Currie, D. J., Diniz-Filho, J. A. F., Guégan, J. F., Kaufman, D. M., Kerr, J. T., Mittelbach, G. G., Oberdorff, T., O’Brian, E. M. and Turner, J. R. G.: Spatial species-richness gradients across scales: a meta-analysis. J. Biogeogr., 36, 132-147, https://doi.org/10.1111/j.1365-2699.2008.01963.x, 2009.

Formoso, M. L. L., Retzmann, K. and Valeton, I.: Fractionation of rare earth elements in weathering profiles on phonolites in the area of Lages, Santa Catarina, Brazil, Geochimica Brasiliensis, 3, 51-61, 1989.

Garnatje, T., Susanna, A. and Messeguer, R.: Isozyme studies in the genus Cheirolophus (Asteraceae: CardueaeCentaureinae) in the Iberian Peninsula, North Africa and the Canary Islands. P1. Syst. Evol., 213, 57-70, 395 https://doi.org/10.1007/BF00988908, 1998.

Garcia, M., Fre, F. and Grooms, D.: Petrology of volcanic rocks from Kaula Island, Hawaii, Contrib. Mineral. Petr., 94, 461471, https://doi.org/10.1007/BF00376339, 1986.

Gaston, K. J.: Global patterns in biodiversity, Nature, 405, 220-227, https://doi.org/10.1038/35012228, 2000. 
https://doi.org/10.5194/bg-2021-107

Preprint. Discussion started: 5 May 2021

(c) Author(s) 2021. CC BY 4.0 License.

Giladi, I., May, F., Ristow, M., Jeltsch, F. and Ziv, Y.: Scale-dependent species-area and species-isolation relationships: a

review and a test study from a fragmented semi-arid agro-ecosystem. J. Biogeogr., 41: 1055-1069, https://doi.org/10.1111/jbi.12299, 2014.

Gillespie, R. G. and Roderick, G. K.: Geology and climate drive diversification, Nature, 509, 297-298, https://doi.org/10.1038/509297a, 2014.

Gray, M.: Geodiversity. Valuing and Conserving Abiotic Nature, John Wiley \& Sons Ltd, Chichester, 2004.

405 Gray, M.: Comment. Other nature: geodiversity and geosystem services, Environ. Conserv., 38, 271-274, https:// doi:10.1017/S0376892911000117, 2011.

Hagos, M., Koeberl, C. and Jourdan, F.: Geochemistry and geochronology of phonolitic and trachytic source rocks of the Axum obelisks and other stone artifacts Axum, Ethiopia, Geoheritage, 9, 479-494, https://doi.org/10.1007/s12371-016-01997, 2017.

410 Hall, K., Lindgren, B. S. and Jackson, R.: Rock albedo and monitoring of thermal conditions in respect of weathering: some expected and some unexpected results, Earth Surf. Proc. Land., 30, 801-811, https://doi.org/10.1002/esp.1189, 2005.

Harrison, S., Safford, H. D., Grace, J. B., Viers, J. H., and Davies, K. F.: Regional and local species richness in an insular environment: serpentine plants in California, Ecol. Monogr., 76, 41-56, https://doi.org/10.1890/05-0910, 2006.

Harrison, S. P. and Rajakaruna, N.: Serpentine: The Evolution and Ecology of a Model System. University of California 415 Press, Berkeley, 2011.

Harter, D. E. V., Irl, S. D., Seo, B., Steinbauer, M. J., Gillespie, R., Triantis, K. A., Fernández-Palacios, J.-M. and Beierkuhnlein, C.: Impacts of global climate change on the floras of oceanic islands-Projections, implications and current knowledge. Perspect. Plant Ecol. Evol. Syst., 17, 160-183, https://doi.org/10.1016/j.ppees.2015.01.003, 2015.

Hjort, J., Gordon, J. E., Gray, M. and Hunter, M. L.: Why geodiversity matters in valuing nature's stage. Conserv. Biol., 29, 630-639, https://doi.org/10.1111/cobi.12510, 2015.

Hortal, J., Triantis K.A., Meiri, S., Thébault, E. and Sfenthourakis, S.: Island species richness increases with habitat diversity. Am. Nat., 174, 207-217, https://doi.org/10.1086/645085, 2009.

Hulshof, C. M. and Spasojevic, M.J.: The edaphic control of plant diversity. Global Ecol Biogeogr, 29, 1634-1650, https://doi.org/10.1111/geb.13151, 2020.

425 Irl, S. D. H., Harter, D. E. V., Steinbauer, M. J., Gallego Puyol, D., Fernández-Palacios, J. M., Jentsch, A., and Beierkuhnlein, C. (2015). Climate vs. topography-spatial patterns of plant species diversity and endemism on a highelevation island. J. Ecol., 103, 6, 1621-1633.

Kazakou, E., Adamidis, G. C., Baker, A. J., Reeves, R. D., Godino, M., and Dimitrakopoulos, P. G.: Species adaptation in serpentine soils in Lesbos Island (Greece): metal hyperaccumulation and tolerance, Plant Soil, 332, 369-385, https://doi.org/10.1007/s11104-010-0302-9, 2010.

Kier, G., Kreft, H., Lee, T. M., Jetz, W., Ibisch, P. L., Nowicki, C., Mutke, J. and Barthlott, W.: A global assessment of endemism and species richness across island and mainland regions, PNAS, 106, 9322-9327, https://doi.org/10.1073/pnas.0810306106, 2009. 
https://doi.org/10.5194/bg-2021-107

Preprint. Discussion started: 5 May 2021

(c) Author(s) 2021. CC BY 4.0 License.

Kruckerberg, A. R.: An essay: Geoedaphics and island biogeography for vascular plants, Aliso, 13, 225-238, 1991.

435 Lawler, J. J., Ackerly, D. D., Albano, C. M., Anderson, M. G., Dobrowski, S. Z., Gill, J. L., Heller, N. E., Pressey, R. L., Sanderson, E. W., Weiss, S. B.: The theory behind, and the challenges of, conserving nature's stage in a time of rapid change, Conserv Biol., 29, 618-629, https://doi.org/10.1111/cobi.12505, 2015.

Liu, J., Möller, M., Gao, L., Poudel, R. C. and Li, D.: Geological and ecological factors drive cryptic speciation of yews in a biodiversity hotspot, New Phytol., 199, 1093-1108, https://doi.org/10.1111/nph.12336, 2013.

440 Liu, J., Matthews, T. J., Zhong, L., Liu, J., Wu, D. and Yu, M.: Environmental filtering underpins the island species-area relationship in a subtroppical anthropogenic archipelago. J. Ecol., 108, 424-432, https://doi.org/10.1111/1365-2745.13272, 2020 .

MacArthur, R. H. and Wilson, E. O: The Theory of Island Biogeography. Monographs in Population Biology no. 1. Princeton University Press, Princeton, NJ, 1967.

445 Manning, D. A. C.: Mineral sources of potassium for plant nutrition. A review, Agron. Sustain. Dev., 30, 281-294, https://doi.org/10.1051/agro/2009023, 2009.

Matthews, T. J., Guilhaumon, F., Triantes, K. A., Borregaard, M. K. and Whittaker, R. J.: On the form of species-area relationships in habitat islands and true islands, Global. Ecol. Biogeogr., 25, 847-858, https://doi.org/10.1111/geb.12269, 2016.

450 Middlemost, E. A. K.: San Miguel de La Palma - A volcanic island in section, Bull Volcanol, 34, $216-239$. https://doi.org/10.1007/BF02597787, 1970.

Middlemost, E. A. K.: Evolution of La Palma, Canary Archipelago, Contr. Mineral. and Petrol., 36, 33-48, https://doi.org/10.1007/BF00372833, 1972.

Muer, T., Sauerbier, H. and Cabrera Calixto, F.: Die Farn- und Blütenpflanzen der Kanarischen Inseln, Margraf Publishers,

455 Weikersheim, 2016.

Nockolds, S. R.: Average chemical composition of some igneous rocks, Bull. Geol. Soc. Am., 65, 1007-1032, 1954.

Paulay, M.: Biodiversity on oceanic islands: Its origin and extinction, Am. Zool., 34, 134-144, https://www.jstor.org/stable/3883824, 1994.

Pausas, J. G., Carreras, J., Ferré, A., Font, X.: Coarse-scale plant species richness in relation to environmental heterogeneity.

J. Veg. Sci, 14, 661-668, https://doi.org/10.1111/j.1654-1103.2003.tb02198.x, 2003.

Porder, S., Paytan, A. and Vitousek, P.M.: Erosion and landscape development affect plant nutrient status in the Hawaiian Islands, Oecologia, 142, 440-449, https://doi.org/10.1007/s00442-004-1743-8, 2005.

POWO: Plants of the World Online. Facilitated by the Royal Botanic Gardens, Kew, 2019: http://www.plantsoftheworldonline.org/, last access 06 January 2021.

465 Ramos, L. A., Nolla, A., Korndörfer, G.H., Pereira, H.S. and Camargo, M.S.: Reatividade de corretivos da acidez e condicionadores de solo em colunas de lixiviação, Rev. Bras. Cienc. Solo., 30, 849-57, 2006. 
https://doi.org/10.5194/bg-2021-107

Preprint. Discussion started: 5 May 2021

(c) Author(s) 2021. CC BY 4.0 License.

(c) (i)

Ricketts, T. H.: The matrix matters: Effective isolation in fragmented landscapes, Am. Nat., 158, 87-99, https://doi.org/10.1086/320863, 2001.

Rosenzweig, M.: Species diversity in space and time. Cambridge: Cambridge University Press, https://doi:10.1017/CBO9780511623387, 1995.

Schoen, C., Aumond, J. J. and Stuermer, S. L.: Efficiency of the on-Farm mycorrhizal inoculant and phonolite rock on growth and nutrition of Schinus terebinthifolius and Eucalyptus saligna, Rev. Bras. Cien. Solo., 40, 1-14, http://dx.doi.org/10.1590/18069657rbcs20150440, 2016.

Spürgin, S., Weisenberger, T. B., and Marković, M.: Zeolite-group minerals in phonolite-hosted deposits of the Kaiserstuhl

Volcanic Complex, Germany, American Mineralogist, 104.5, 659-670, https://doi.org/10.2138/am-2019-6831, 2019.

Tukiainen, H., Bailey J. J., Field, R., Kangas, K. and Hjort, J.: Combining geodiversity with climate and topography to account for threatened species richness, Conserv. Biol., 31, 364-375, https://doi.org/10.1111/cobi.12799, 2016.

Vitales, D., Garnatje, T., Pellicer, J., Vallès, J., Santos-Guerra, A. and Sanmartín, I.: The explosive radiation of Cheirolophus(Asteraceae, Cardueae) in Macaronesia, BMC Evol. Biol., 14, 1-15, https://doi.org/10.1186/1471-2148-14-118, 480 2014a.

Vitales, D., García-Fernández, A., Pellicer, J., Vallè, J., Santos-Guerra, A., Cowan, R.S., Fay, M.F., Hidalgo, O. and Garnatje, T.: Key processes for Cheirolophus (Asteraceae) diversification on oceanic islands inferred from AFLP Data, Plos ONE, 9, e113207, https://doi.org/10.1371/journal.pone.0113207, 2014b.

von Fragstein, P., Pertl, W. and Vogtmann, H.: Artificial weathering of silicate rock powders, Z. Pflanz. Bodenkunde, 151, 485 141-146, https://doi.org/10.1002/jpln.19881510214, 1988.

von Wilpert, K. and Lukes, M.: Ecochemical effects of phonolite rock powder, dolomite and potassium sulfate in a spruce stand on an acidified glacial loam, Nutr. Cycl. Agroecosys., 65, 115-27, https://doi.org/10.1023/A:1022103325310, 1998.

Walentowitz, A., Kienle, D., Sungur, L. and Beierkuhnlein, C.: Vegetation plot and trait data from phonolitic and basaltic rocks on La Palma (Canary Islands, Spain) [submitted].

490 Whittaker R. J. and Fernández-Palacios, J.-M.: Island Biogeography: Ecology, Evolution, and Conservation, $2^{\text {nd }}$ ed., Oxford University Press, Oxford, 2007. 